\title{
Policy Analysis in Times of Austerity: Puzzling in the Shadow of Powering?
}

\author{
Editors: Frans K.M. van Nispen \& Peter W.A. Scholten ${ }^{1}$
}

\section{Introduction}

The global financial crisis has created an almost unparalleled process of politicization and policy change. However, has the crisis also been a window of opportunity for policy learning? To put it differently, has policy change been driven by puzzling or rather by powering? In this second special issue on the policy analysis at times of a [perceived] crisis we address the role of policy analysts and the outcome of their work in times of austerity due to the global financial crisis ${ }^{2}$. What is the impact of the financial and economic circumstances on the application and utilization of policy analysis? What is the added value of arguments and information when the government is running short of funding and out of time? Does the crisis provide opportunities or obstacles to policy learning? As policy making 'entails both intellectual puzzling over what to do under conditions of uncertainty and bounded rationality, and political powering between competing interests' [Heclo 1974; 305306; Hall 1993: 289; Hemerijck \& Van Kersbergen 1999: 176] one may question if policy change, if any, is primarily due to puzzling [policy analysis, policy learning] or rather powering in times of austerity.

The papers presented in both issues have been delivered at the $4^{\text {th }}$ ICPA Comparative Research Symposium in Rotterdam [22-24 November 2012]. This symposium dealt with policy analysis during crises, addressing the relation between policy analysis and policy change at times of crisis. The papers were thematically grouped in a special issue on the migration crisis and one on the global financial crisis $^{3}$.

1. Frans van Nispen is Associate Professor of Public Administration at Erasmus University Rotterdam, the Netherlands. He has published in various journals, primarily on issues at the interface of policy analysis and public budgeting in the European context. He served as co-editor [with Peter Scholten] of Policy Analysis in the Netherlands, recently published by the Policy Press [2014]. Contact: vannispen@fsw.eur.nl

Peter Scholten is Associate Professor Public Policy \& Politics at Erasmus University Rotterdam. $\mathrm{He}$ is co-director of IMISCOE, a European network in the field of International Migration, Integration and Social Cohesion. He has published in various journals and has published various books, in particular about the role of knowledge in policymaking and on intercultural governance]. Contact: p.w.a.scholten@fsw.eur.nl

2. The first issue showed that the politicization of migration changed [rather than diminished] he role of policy analysis in migration policy dynamics [Scholten and Van Nispen 2015].

3. In addition, one article on the environmental crisis will be published in JCPA separately [Van Buuren et al., forthcoming]. 


\section{The Global Financial Crisis}

The global financial crisis dates from the subprime mortgage crisis in the US [2007-2009] due to the bursting of the housing bubble. Soon, the banking crisis spread to other parts of the world as many banks happened to own 'toxic assets'. The interbank lending market almost completely dried-up, inducing a credit crunch and by such affecting the real economy as reflected in a shrinking economic growth and a growing unemployment, notable among starters at the labor market [Gros \& Alcidi 2010]. The economic crisis turned into a sovereign debt crisis [ $>2009$ ] when countries were 'forced' to bailout their banks, if not to save their national champions by using taxpayer money, boosting debt ratio to extreme heights. Not long after the financial market started to question the capacity of the government of various European member states, notably Greece, to pay their debts. The interest-rate of government bonds of countries with shaky public finances raised sharply and the spread the deviation of the interest rates of government bonds - widened rapidly [The Economist, March 27, 2008].

Figure 1: The Euro's Three Crises

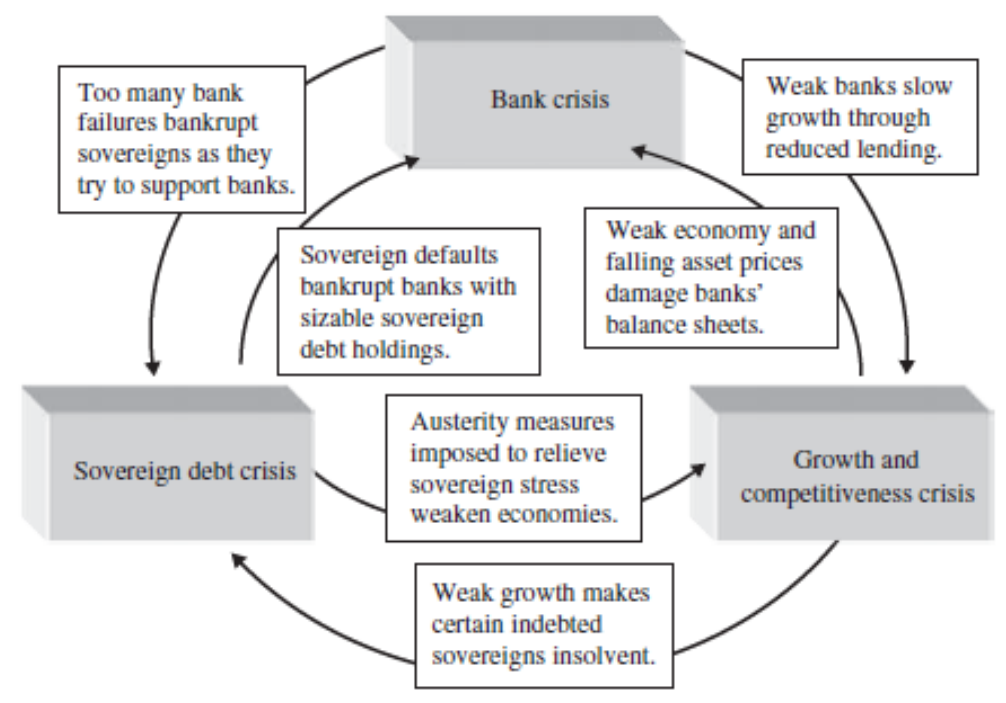

Source: Shambaugh 2012.

The three crises - banking crisis, economic crisis and sovereign debt crisis - cannot be separated from each other. As is argued correctly by Jay Shambaugh, the euro area is facing three interlocking crises that together challenge the viability of the euro. Consequently, 'the solution to one will be undone by the others unless they, too, are resolved' [Shambaugh 2012: 158; Kickert 2012; Kickert et al. 2013]. Taking the mutual relationship between the three crises into account we will focus on the added value of policy analysis, i.e. arguments and information in the context of the global financial crisis. 
A survey among senior executives in ten countries [ $N=4814$; Response 23,71 per cent] reveals that the relevance of performance information has increased, at least to their opinion, in response to the consequences of the global financial crisis [Hammerschmid et al. 2013]. At the same time the OECD reports a decline of performance information as result of its survey of budget practices and procedures. In general it appears that line ministries used performance information less during the negotiations of next year's budget as compared with the findings of the previous survey [2007 vs. 2011]. In addition, more countries report that no performance information is used during the negotiations [OECD 2014, 76-77]. The explanation for this seemingly contradictory information may be twofold. First, the utility of performance information may be still growing in most areas, but the constraints of performance information have become eminent in the field of public budgeting. It is nowadays more or less accepted that about 40 per cent of the budget is applicable to performance information. Unfortunately, the COCOPS-report did not address the relevance and utility of performance information in the field of public budgeting. Second, none of the surveys happens to be conclusive as there is quite some variation underneath at the disaggregated level of the individual countries both in terms of ambition and intention as well as across sectors.

\section{Shifts in Policy Analysis}

The conventional policy analysis is focused on the goal achievement, effectiveness and efficiency. To a considerable extent, a policy analyst was guided by a 'logic of consequence'. Policy analysis was regarded as a type of 'social engineering'. Since, policy analysis has gradually expanded its domain in response to the relatively low utilization of the findings of social research and the growing participation of interest groups and stakeholders. The outcome is a more institutional policy analysis that is also guided by the 'logic of appropriateness' [Van Hemerijck 2001].

In general, four stages may be distinguished in the development of policy analysis. In the first stage policy was regarded as something that could be more or less implemented. On the one hand, the limited utilization of the findings of social research led to lower expectations and to a more relativist stand regarding the added value of social research. The function of social research was mainly in providing 'enlightenment'. On the other hand, the limited utilization of the findings of social research has induced all kind of various attempts to enhance the potential utility of the results of policy analysis.

The call by Allison [1974] and Wolf [1979] to complement or to expand policy analysis by implementation analysis marks the second stage. Policy analysis should no longer limit itself to an assessment of the technical feasibility, but it should also include an appraisal of political feasibility and societal acceptance of the potential solutions. This approach was initially 'top down', assuming that policy implementation would follow due course as intended at the drawing table. This model was abandoned and replaced by a pluralistic 
model as a consequence of the proliferation of policy analysis. It is nowadays accepted that the government is no longer 'the conductor ... of an orchestra, but one of the musicians [Van Nispen \& Ringeling 1998: 210].

In the pluralistic model, various actors use the services of a policy analyst and/or policy analytical methods and techniques. The result is an amalgam of partially competing, partially overlapping policy analytical studies that do not clarify, but rather muddle the fair assessment of different interests. Not only the definition of the problem and consequently the potential solution vary, but also the underlying assumptions with a 'battle of analyses' [Goemans 1988: 351] or 'dueling swords' [Radin 2013: 30] as a result. On top of that the government is often faced with the almost impossible task of finding a common denominator [Klaassen \& Van Nispen 1996].

The argumentative turn in policy analysis, which comes in various configurations [Hoppe 1998], marks the last stage in the development of policy analysis and constitutes on a paradigm shift. Logical positivism and critical rationalism are replaced by a more socialconstructivist epistemology. The focus not only shifted to the generation of arguments, but also to the symbolism and rhetoric [Hoppe 1998: 15]. The aim of policy analysis is no longer to provide 'objective' information, if possible at all, but to achieve inter-subjective agreement between competing interests. However, it would be wrong to believe that the collection and digestion of policy relevant information is no longer important. To the contrary, research is an activity of selecting policy arguments to the test of persuasiveness, rather than quasi-scientific proof or rational 'truth' [Parsons 1995: 441].

The gradual expansion of the domain of policy analysis is not without consequences for the role of the policy analyst. The policy analyst has become a producer of arguments, more similar to a lawyer - a specialist in legal arguments - than to an engineer or a scientist [Majone 1989: 21]. He serves as a 'facilitator' to assist citizens in their efforts to examine their own interests and to make their own decisions [Fischer 1998: 18; Fischer 2003: 216; Fischer 2012: ..]. The main objective of a policy analyst is to create the conditions for what Habermas has called an 'ideal speech situation'.

\section{Crisis as a Window of Opportunity for Policy Learning?}

A key question in this special issue [as for the first issue on the migration crisis], is whether policy analysis contributes to policy learning at times of crisis. Does a crisis, in this case the global financial crisis, provide opportunities or rather obstacles for policy learning. Sabatier [1993: 19] defines policy learning as 'relatively enduring alterations of thought or behavioral intentions that are concerned with the attainment [or revision] of the precepts of a policy belief system'. Policy learning can be driven by information and knowledge, including expert knowledge as well as lay knowledge, but also by frames, ideas, values and plain experiences. 
The role of policy analysis has been hypothesized very differently in the course of time [see also Scholten and Timmermans 2010]. In the first stage or 'generation' of policy analysis, the idea was that policy analysis would 'enlighten' policymakers by 'speaking truth to power.' In the second stage, policy analysis became incorporated into more technocratic processes of policymaking in which the knowledge provided by policy analysis was key to policy development and implementation. This stage is very much alive today as well in terms of 'evidence-based policy making.' In the third stage, the role of policy analysis became more modest again, in the context of a more pluralist process in which knowledge could sometimes help pacify controversies but could also be used as political ammunition. Finally, in the fourth stage, policy analysis can contribute to policy learning only indirectly, amongst others by critically examining discourses and frames and contributing to a process of frame reflection.

Few scholars have thus far focused specifically on the role of policy analysis in policy learning at times of crisis. One particularly valuable contribution that we like to mention is by Solesbury [2001], who shows that the crisis induced or at least strengthened the revival of the rational model and the pursuit of evidence-based policy making. Referring to the standing practice in health care, we feature a 'utility turn' to 'what works' [Solesbury 2001] as, inter alia, reflected in the growing interest in spending reviews which are geared towards 'smart cuts' in order to reestablish fiscal consolidation.

However, various scholars conclude more in general that the role of policy analysis can no longer adequately be understood in terms of the enlightenment or rational models [first and second generations of policy analysis] in the context of contemporary late-modern societies. A key characteristic of late modernity is the focus on uncertainty and risk. The society is more than ever aware that there are unknowns and that man-made institutions and technologies also carry risks that cannot be foreseen. Scientific knowledge, i.e. information that has been put to a test, is increasingly contested by non-scientific information from other 'knowledge reservoirs' such as 'laymen's knowledge' and even 'fact-free politics' [Bekkers 2014: 238-242]. How these sources of information interact in a real life situation is still very much unclear [Head 2008: 7]. Therefore, many scholars and practitioners remain skeptical about the potential impact of evidence-based policy making [Van Twist et al. 2014]. Note, that this may even more applicable in times of crisis because there is hardly room to conduct social research, although the attention to spending reviews seems to point in another direction. Time is traded-off to a more evidence-based policy geared to fiscal consolidation.

The contributions to this special issue confirm that the role of policy analysis in inducing learning at times of crisis seems rather limited. Fenger \& Qualia in their cross-national comparison of the response to the global financial crisis: 'have policy makers learnt their lessons?' adopt a pluralist lens on policy learning, and find only instrumental forms of learning on secondary policy aspects rather than on more fundamental policy premises. A similar question is raised by Zahariadis in his contribution to this special issue. The outcome is somewhat ambiguous: policy learning is mixed according to Fenger and Qualia from a 
longitudinal as well as from a comparative perspective, whereas Zahariadis comes to the conclusion that policy learning takes place even though 'powering' overwhelms 'puzzling' in times of austerity. However, the appreciation of policy learning seems to be affected by the [theoretical] point of departure. Applying the advocacy coalition framework by Sabatier et al. Fenger and Qualia expect to find policy learning. By contrast, Zahariadis did not expect to find policy learning in the case of the Greek sovereign debt crisis. We do not claim that they meet somewhere in the middle, but the glass is clearly half empty or half full.

The issue of policy learning may be addressed too in the context of a broader set of factors that may account for policy change. All contributors draw the conclusion that policy change, if any, is induced by exogenous factors, i.e. the global financial crisis. However, the articles in this issue did not find a paradigm shift, although the global financial crisis may be considered as a 'critical junction'. In addition, one may look at the degree of policy change. As mentioned previously, Fenger and Qualia conclude that policy learning has to do with policy instruments rather than policy objectives. A similar observation is made by Brans et al. who are drawing the conclusion that most changes in their case of the caretaker government in Belgium were first and second order changes which do not extend beyond the calibration of policy instruments.

\section{Contributions to this volume}

The special issue is composed of four articles which address various aspects and fields of the global financial crisis: the reduction of personnel in Greece in order to deal with the consequences of the sovereign debt crisis, the regulation of financial institutions in the EU and two of its member states - the Netherlands and the United Kingdom - in response to the banking crisis, the pursuit of spending reviews in Canada and the Netherlands in order to reestablish fiscal consolidation and the interplay of the global financial crisis and the political crisis that has held Belgium for such a long time.

As for the comparative angle, two contributions can be characterized as qualitative single case study on Belgium and Greece respectively, while the other two can be seen as small-n case studies. The theoretical angle varies from contribution to contribution though all seem to be fascinated by the interplay between 'puzzling' and 'powering'. The empirical data cover a broad spectrum of efforts to deal with the consequences of the global financial crisis, ranging from financial regulations to personnel reduction and spending reviews.

The first paper by Menno Fenger and Lucia Qualia - The global financial crisis in comparative perspective: have policy makers 'learnt their lessons'? - examines the regulatory response of the European Union as well as two of its member states - The Netherlands and the United Kingdom - to the global financial crisis. Building on Sabatier's advocacy coalition framework $[\mathrm{AFC}]$ to policy change and learning they come the conclusion that the regulatory response do not constitute no paradigm shifts. Why was policy-learning limited? The conditions for learning as identified by Sabatier were not in place. The level of conflict between the 
advocacy coalitions within a subsystem was high, especially after the politicization of financial regulation in the wake of the crisis. Moreover, the availability of reliable, quantitative data and clear causal loops were missing. The study confirms that the outcome of policy analysis is primarily used as argumentative input in the exchange of beliefs and resources between advocacy coalitions. Policy analysts are seen as 'players' rather than as 'referees' deciding which argument is correct. Consequently, the impact of policy analysis is limited, especially in the case of high politics, such as the regulation of the financial sector in response to the sovereign debt crisis.

The second paper by Frans van Nispen - Policy analysis in times of austerity: a cross-national comparison of spending reviews - is looking at the efforts to re-establish fiscal consolidation. As across-the-board cuts and one-off measures are no longer adequate, a more evidencebased policy is needed to reduce the budget deficit and debt accumulation. One promising route to fiscal consolidation is the establishment of spending reviews, which may be considered as a form of integrated policy analysis aimed at the generation of smart cuts. The empirical data are primarily taken from two OECD countries - Canada and the Netherlands with a long-standing tradition of spending reviews. At face value the effect of spending reviews seems to be modest, but one should note that 'research rarely drives policy' [Haskins 2009: 28]. The country experience indicates that the impact of spending reviews should not be overestimated, as the consequences of the sovereign debt crisis go beyond the scope of spending reviews. The evidence may be weak, but they provide insight in the effects of the potential savings and, as such, prepare the ground for an evidence-based fiscal policy.

The third paper is by Nikos Zahariadis - Powering over puzzling? Downsizing the public sector during the Greek sovereign debt crisis - is addressing the question of policy learning in times of crisis with stark distributive consequences. Applying Schneider and Ingram's policy design framework to the reduction of personnel in the public sector during the Greek sovereign debt crisis, he comes to the conclusion that powering explains policy change if policies are conceived and designed abroad, read the Troika in the case of the Greek sovereign debt crisis $^{4}$. However, powering does not exclude policy learning as learning 'under conditionality requirements' [Dunlop \& Radaelli 2013] and policy failure help actors to get around formal requirements using targets and standards to their benefit. The outcome of the study enriches by such Schneider and Ingram's claim that policy design may be attributed to social construction and political power of target groups and may have implications for the body of knowledge on policy design and policy learning.

The fourth paper by Marleen Brans, Valérie Pattyn and Geert Bouckaert - Taking care of crisis: policy continuity and change under Belgium's longest caretaker government - analyses the phenomenon of policy continuity and change during this double crisis: an endogenous political one, and an exogenous financial one. The analysis illustrates how the financial crisis

4. The Greek government is under supervision of the Troika consisting of the European Commission, the European Central Bank [ECB] and the International Monetary Fund [IMF]. 
overrode the political crisis and confirms the importance of international determinants of policy change. However, the exogenously induced policy change was largely mitigated by the caretaker rule. While the literature suggests that exogenous factors of the gravity presented by the Eurozone crisis induce third order change, most changes were first and second order changes [Hall 1993] and did not extend beyond the calibration of policy instruments. It was only after a government was duly appointed that policy change moved to priority setting, targeted cutbacks, and innovation of objectives.

So, where do we stand? All papers indicate the global financial crisis as an exogenous variable has induced policy change. Besides, policy change seems to be primarily due to powering; puzzling takes mainly place in the shadow of powering. The role of policy analysis is limited, notably in high politics. Most policy learning cumulated into first and second order changes. Contrary to what one would expect on the basis of the body of knowledge, a new paradigm [third order change] has not yet emerged so far [Hall 2013]. Furthermore, context variables, such as the political situation and vested interests, serve as intervening variables. Only when they are favorable and receptive, policy learning is effectively turned into policy change. The conclusion may have important consequences for the body of knowledge on policy analysis as well as policy learning and policy change. 


\section{References}

Allison, G.T. [1975], Implementation Analysis: The Missing Chapter in Conventional Analysis. A Teaching Exercise, in: W.A. Niskanen et al. [eds.], Benefit-Cost and Policy Analysis, Chicago: Aldine Publishers.

Bekkers, V.J.J.M. [2014], Contested Knowledge in theory driven Policy Analysis: Setting the Dutch Stage, in: Van Nispen \& Scholten, op. cit. 2014.

Dunlop, C.A. \& C.M. Radaelli [2013], Systematizing policy learning: from monolith to dimensions. Political Studies, 61 [3]. doi: 10.1111/j.1467-9248.2012.00982.x.

Fischer F. [2003], Reframing Public Policy: Discursive Politics and Deliberative Practices, Oxford: Oxford University Press.

Fischer, F. \& J. Forester [1993], The Argumentative Turn in Policy Analysis and Planning, Durham/London: Duke University Press.

Fischer, F. \& H. Gottweis, eds. [2012], The Argumentative Turn Revisited: Public Policy as Communicative Practice, Durham: Duke University Press

Goemans, T. [1988], Beleidsanalyse op weg naar volwassenheid, in: A.F.A. Korsten \& Th.A.J. Toonen [red.], Bestuurskunde: hoofdfiguren en kernthema's, Leiden: Stenfert Kroese, 343-359.

Gros, D. \& C. Alcidi [2010], The Impact of the Financial Crisis on the Real Economy, Intereconomics 2010| 1: 4-20.

Hammerschmid, G., A. Oprisor \& V. Štimac [2013], COCOPS Executive Survey on Public Sector Reform in Europe Research Report, COCOPS WP 3.

Haskins, R. [2009], With a scope so wide: using evidence to innovate, improve, manage, budget, in: Australian Government Productivity Commission, Strengthening Evidence-Based Policy in the Australian Federation, Roundtable, Canberra, August 17-18, 2009.

Hall, P. A. [1993]. Policy paradigms, social learning, and the state: the case of economic policymaking in Britain. Comparative Politics, 275-296.

Hall, P. A. [2013], Brother, Can You Paradigm?, Governance: An International Journal of Policy, Administration, and Institutions 26 [2]: 189-192.

Heclo, H. [1974]. Modern social politics in Britain and Sweden: From relief to income maintenance: Yale University Press New Haven CT, and London. 
Hemerijck, A. [2001], De institutionele beleidsanalyse: naar een intentionele verklaring van beleidsverandering, in: T. Abma en R. in 't Veld [eds.], Handboek Beleidswetenschap, Meppel: Boom, 83-95.

Hemerijck, A. \& K. van Kersbergen [1999], Negotiated Policy Change: Towards a Theory of Institutional Learning in Tightly Coupled Welfare States, in: D. Braun \& A. Busch [eds.], 1999, Public Policy and Political Ideas, Cheltenham: Edward Elgar, 168-185.

Hoppe, R. [1998], De broosheid van debat en argumentatieve beleidsanalyse, Enschede: Universiteitsdrukkerij.

Kickert, W.J.M. [2012], Europa en de Crisis. Hoe Europese overheden omgingen met de bankencrisis, economische crisis en de begrotingscrisis in 2008-2011, Rotterdam: Erasmus Universiteit Rotterdam.

Kickert, W, T. Randma-Liiv \& R. Savi [2013], Fiscal Consolidation In Europe: A Comparative Analysis, COCOPS Trend Report.

Klaassen, H.L. \& F.K.M. van Nispen [p1996], De wildgroei van effectrapportages. Een rapportage, Bestuurskunde 5 [7]: 308-316.

Majone, G. [1989], Evidence, Argument and Persuasion in the Policy Process, New Haven: Yale University Press.

OECD [2014], Budgeting Practices and Procedures in OECD Countries, Paris: OECD.

Parsons, W. [1995], Public Policy. An Introduction to the Theory and Practice of Policy Analysis, Aldershot/Brookfield: Edward Elgar.

Radin, B. [2013], Beyond Machiavelli: Policy analysis comes of age, Washington: Georgetown University Press [2nd edition].

Sabatier, P.A. [1998], The advocacy coalition framework: revisions and relevance for Europe, Journal of European Public Policy, 5, 1: 98-130.

Shambaugh, J. C. [2012], The Euro's Three Crises, Brookings Papers on Economic Activity, Spring 2012: 157-165.

Solesbury, W. [2001], Evidence-based Policy: Whence it Came and Where it's Going [London: ECRC Centre for AQ47 Evidence-based Policy and Practice].

Schneider, A.\& H. Ingram [1997], Policy Design for Democracy, Lawrence: University Press of Kansas.

Scholten, P. and A. Timmermans [2010]. Setting the Immigrant Policy Agenda: Expertise and Politics in France, the UK and the Netherlands. In: Journal of Comparative Policy Analysis, 12, 527-543. 
Scholten, P.W.A. and Van Nispen, F.K.M. [2014]. Policy Analysis at Times of Crises: the Migration Crisis. In: Journal of Comparative Policy Analysis, 17:1, 1-10.

Van Buuren A., M. Vink and J. Warner, Constructing authoritative answers to a latent crisis. The politics of climate adaptation in the Netherlands: puzzling, powering and framing, Journal of Comparative Policy Analysis ../.. [forthcoming].

Van Nispen, F.K.M. \& A.B. Ringeling [1998], On instruments and Instrumentability: A Critical Assessment, in: B. Guy Peters \& Frans K.M. van Nispen, eds., Public Policy Instruments: Evaluating the Tools of Public Administration, Aldershot: Edward Elgar.

Van Nispen, F.K.M. and P.W.A. Scholten, eds. [2014], Policy Analysis in the Netherlands, Bristol: Policy Press.

Van Twist, M., R. Rouw \& M. van der Steen [2014], Policy Analysis in Practice: Reinterpreting the Quest for Evidence-Based Policy, in: Van Nispen \& Scholten, op. cit. 2014.

Wolf, Ch. [1979], A Theory of Nonmarket Failure: A Framework for Implementation Analysis, Journal of Law and Economics 22 [1]: 107-139. 